\title{
Evidence of ocean warming in Uruguay's fisheries landings: the mean temperature of the catch approach
}

\author{
Ignacio Gianelli ${ }^{1, *}$, Leonardo Ortega ${ }^{2}$, Yamandú Marín ${ }^{2}$, Alberto R. Piola ${ }^{3,4}$, Omar Defeo ${ }^{1}$ \\ ${ }^{1}$ Unidad de Ciencias del Mar (UNDECIMAR), Facultad de Ciencias, Universidad de la República, 11400 Montevideo, Uruguay \\ ${ }^{2}$ Dirección Nacional de Recursos Acuáticos, 11200 Montevideo, Uruguay \\ ${ }^{3}$ Departamento Oceanografía, Servicio de Hidrografía Naval (SHN), C1270ABV, Ciudad Autónoma de Buenos Aires, Argentina \\ ${ }^{4}$ Departamento de Ciencias de la Atmósfera y los Océanos, Universidad de Buenos Aires, C1428EGA, \\ Ciudad Autónoma de Buenos Aires, Argentina
}

\begin{abstract}
Distribution, abundance and life history traits of marine fish and invertebrates are increasingly affected by ocean warming. Consequently, landings of traditional fisheries and their relative species composition could potentially be modified. The mean temperature of the catch (MTC) concept, which refers to the average inferred temperature preference of exploited species weighted by their annual catch for a given area, was applied to Uruguay's industrial fisheries. This approach allowed us to assess the evidence of ocean warming in long-term Uruguayan landings (1973-2017), which were mostly obtained from a major marine warming hotspot. Results showed a marked shift in MTC through time, with the first 10-15 yr characterized by a decreasing trend, but subsequently increasing steadily over time. Long-term effects of ocean warming have led to a shift from cool-water to warm-water species in the relative representation of local landings. A significant and consistent association between sea surface temperature and MTC increase was observed, even when accounting for other drivers. This study provides the first quantitative evidence that ocean warming has been increasingly affecting Uruguayan industrial fisheries during the past decades, and calls for an urgent need to consider environmental changes to properly manage fish stocks, particularly those shared with neighboring countries.
\end{abstract}

KEY WORDS: Climate change - Ocean warming - Fisheries - Mean temperature of the catch . Uruguay

\section{INTRODUCTION}

Ocean warming has profound and well-documented impacts on fisheries (Perry et al. 2005, HoeghGuldberg \& Bruno 2010, Free et al. 2019). The economy and the livelihood of communities that depend on marine resources for food security are being increasingly threatened by rising ocean temperature (Allison et al. 2009, Hobday et al. 2016). Marine species respond to ocean warming by altering their depth (Dulvy et al. 2008) and/or latitudinal range (Cheung et al. 2009, Pinsky et al. 2013), mostly shifting their distributional range poleward (Madin et al.

${ }^{*}$ Corresponding author: ignaciogianelli@gmail.com
2012, Pecl et al. 2017). On a global scale, ocean warming has been inhomogeneous. Hobday \& Pecl (2014) identified several marine hotspots, which are regions where the sea surface temperature (SST) has increased most rapidly over the period 1950-2000 and are projected to continue changing at a faster rate than the global average. As marine species respond to ocean warming (Pinsky et al. 2013), these hotspots could affect the distribution, abundance and life history traits of fish (Pauly \& Cheung 2018) and invertebrates (McLachlan \& Defeo 2018), thus affecting catch levels and fisheries targeting traditional resources. This situation is aggravated by the fact that

() The authors 2019. Open Access under Creative Commons by Attribution Licence. Use, distribution and reproduction are unrestricted. Authors and original publication must be credited. 
marine fisheries constitute complex systems that are also influenced by human-induced changes such as exploitation history and management tools (Österblom et al. 2017). Thus, disentangling exploitation patterns from climate change effects represents a major challenge due to the interconnected nature of both drivers (Alheit et al. 2014).

Several approaches have been applied to understand and project impacts of climate change in fisheries (Barange et al. 2010), although most of them fell short on critical aspects such as the role of management measures and resource use in aggravating or mitigating impacts (but see Costello 2018, Gaines et al. 2018). Cheung et al. (2013) developed an innovative and simple approach for assessing the signature of ocean warming in fisheries catches, based on the 'mean temperature of the catch' (MTC), which refers to the average inferred temperature preference of exploited species weighted by their annual catch for a given area (e.g. Large Marine Ecosystems [LMEs] or Economic Exclusive Zones). The underlying ecological theory is that thermal preferences of marine species can be described by a Gaussian function with an optimal inferred temperature. Thus, an increase in MTC would indicate more warm-water species in the catch and/or a decrease in the amount of cool-water species. Recent analyses in the Mediterranean Sea (Tsikliras \& Stergiou 2014) and China's seas (Liang et al. 2018) supported global observations about the increase in the MTC at a regional scale. Other studies used fishery-independent data to estimate and compare MTC results with those obtained using landings data (Keskin \& Pauly 2014, Tsikliras et al. 2015), or took into account habitat characteristics and indirect measures of fishing effects (Maharaj et al. 2018, Tsikliras et al. 2019). However, if not properly addressed, the MTC (based only on catch data) could lead to misleading conclusions. MTC analyses should also consider the effects of fishing effort, markets and industry portfolio diversifications, which can influence the relative composition of the catch.

In the Southwestern Atlantic Ocean (SAO), the continental shelf of southern Brazil, Uruguay and northern Argentina embraces one of the largest marine hot- spots (Hobday \& Pecl 2014). This oceanographic complex region is characterized by high seasonal variations modulated by the confluence of 2 water masses with different thermohaline characteristics (Matano et al. 2010, Piola et al. 2018). Subtropical warm waters are carried southward by the Brazil Current along the shelf break, while subantarctic cold waters are advected northwards by the Malvinas Current (Fig. 1). Their confluence is marked by an array of strongly contrasting water types (Gordon 1989) that define a very energetic and complex region (Fig. 1). Additionally, the Río de la Plata estuary, the major freshwater discharge in the area (average discharge of $22000 \mathrm{~m}^{3} \mathrm{~s}^{-1}$; Guerrero et al. 1997), injects buoyancy and nutrients, thus contributing to system complexity. Furthermore, El Niño Southern Oscillation (ENSO) has a pronounced effect in the

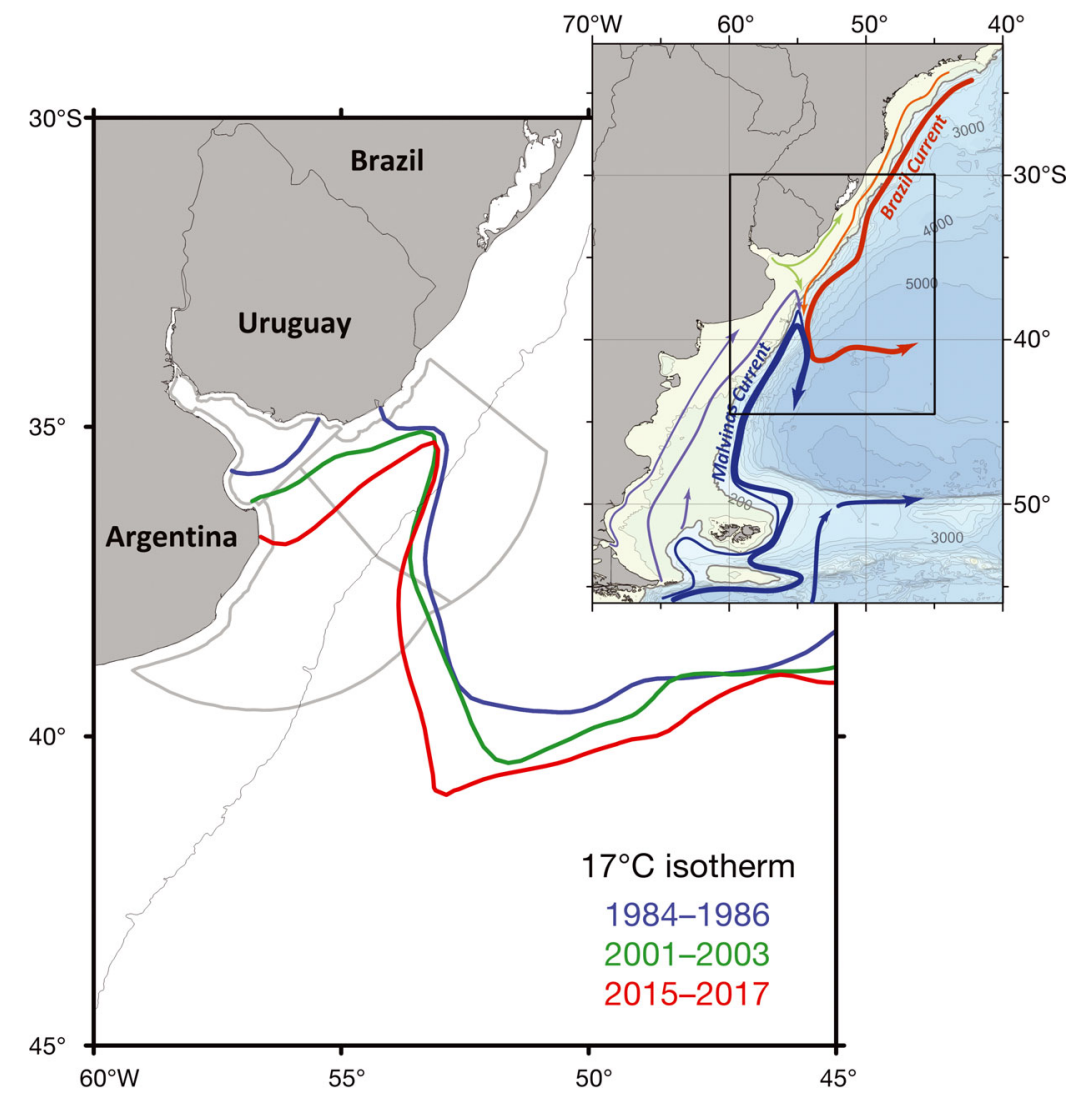

Fig. 1. Mean location of the $17^{\circ} \mathrm{C}$ isotherm (proxy of the latitudinal shift of the warm waters front) derived from sea surface temperature (Reynolds et al. 2007) averaged for the periods 1984-1986 (blue), 2001-2003 (green) and 2015-2017 (red). The Argentinean-Uruguayan Common Fishing Zone is delimited by the grey polygon. The $200 \mathrm{~m}$ isobath is highlighted in gray. The upper panel shows a schematic representation of major ocean currents in the Southwest Atlantic Ocean, with depth (m) indicated by background shading (adapted from Piola et al. 2018) 
area by altering precipitation regimes, which in turn modulate the Río de la Plata discharge magnitude (Piola et al. 2005, 2018). The effect of ENSO on SST anomalies (SSTA) in the SAO is less evident, though lagged northward extensions of cold water were related with ENSO cold phase and the opposite for ENSO warm phase (Colberg et al. 2004 and references therein; Ortega \& Martínez 2007). Critical, but less understood, is the atmosphere-ocean coupling during ENSO events (Ortega \& Martínez 2007, Barreiro 2010). This dynamic oceanographic setting, with a high degree of seasonal and interannual variations, determines a complex horizontal and vertical structure that provides favorable environmental conditions for high primary productivity and also for spawning and breeding of fish and invertebrate populations (Ciotti et al. 1995, Acha et al. 2004, Jaureguizar et al. 2016).

Several studies at a global scale have projected significant mid- and long-term catch losses in the SAO (Cheung et al. 2009, Blanchard et al. 2017, Cheung et al. 2018), seriously threatening an already weakened Uruguayan and Argentinean industrial fishery sector (Villasante et al. 2016, Gianelli \& Defeo 2017). The uncertainty of these global model projections at the regional scale is aggravated by the rapid changes in oceanographic conditions occurring in this hotspot. However, despite the importance and scope of this phenomenon for fisheries and dependent communities, to date there are few studies of the impact of climate change on fisheries in this region (Bertrand et al. 2018). Even more uncertain is the understanding of how environmental change and management policies could interact in aggravating or mitigating climate change impacts (Barange et al. 2010, Gaines et al. 2018). Additionally, the scarcity of fishery-independent data renders it difficult to disentangle multiple, potentially confounding factors, such as changes in fishing pressure, market effects and consumer preferences, from potential climate drivers (Madin et al. 2012, Ortega et al. 2012). Thus, there is an increasing need to provide meaningful evidence of climate change impacts on major fishery resources, with the explicit inclusion of the human dimension. Ideally, this will assist fishery industry and managers in developing adaptation and mitigation plans for regional fisheries in a changing climate.

In this paper, we applied the MTC approach to long-term Uruguayan industrial fishery landings (1973-2017), which are mostly obtained from one of the most energetic and largest marine hotspots. An analysis of a variant of the MTC index was also car- ried out to account for the effect of the dominant species on the composition of the catch. Results were complemented with detailed Uruguayan and Argentinean fishery landings for the period 1996-2017, provided by the binational commission responsible for managing straddling fish stocks in the study area. Finally, the MTC index was modeled to assess the relative contribution of environmental variables and historical exploitation patterns of the Uruguayan fishing fleet.

\section{MATERIALS AND METHODS}

\subsection{The Uruguayan industrial fleet}

The Uruguayan industrial fleet operates on the Río de la Plata estuary (the widest estuary in the world) and in the Argentinean-Uruguayan Common Fishing Zone (AUCFZ). This zone is determined by 2 arcs of circumference of $200 \mathrm{~nm}$ radius, centered at Punta del Este (Uruguay) and Punta Rasa (Argentina) (Fig. 1). The area of the AUCFZ is $218718 \mathrm{~km}^{2}$ and includes almost entirely the Uruguayan Exclusive Economic Zone (EEZ). The Joint Technical Commission of the Uruguayan-Argentinean Maritime Front (CTMFM is its acronym in Spanish) is the regional management and governance body responsible for compiling fishery statistics from both countries, coordinating research plans and performing joint stock assessments for most commercially important resources within the AUCFZ (see the Joint Technical Commission of the Uruguayan-Argentinean Maritime Front for details; http://ctmfm.org/).

Industrial vessels operate, by law, beyond $7 \mathrm{~nm}$ from shore. Most Uruguayan vessels are bottom trawlers. Longlines and pots are used to a lesser extent to target pelagic and benthic resources, respectively. The industrial fishing sector has traditionally represented $>95 \%$ of total Uruguayan landings and currently consists of 50-55 vessels (15-60 m length) with a mean of 360 gross tonnage. More than 50 species are caught by the Uruguayan industrial fishing fleet. However, landings of Argentine hake Merluccius hubbsi, whitemouth croaker Micropogonias furnieri and stripped weakfish Cynoscion guatucupa historically represented more than $85 \%$ of total landings (Gianelli \& Defeo 2017). Landings have drastically fluctuated in the longterm following the phases described by Gianelli \& Defeo (2017): development, expansion, stabilization-diversification and a last phase of declining yields and market contraction. 


\subsection{Fisheries statistics and climatic data}

Uruguayan landings within the AUCFZ (species targeted outside the AUCFZ were excluded from the analysis, i.e. highly migratory tunas and billfishes) and the Río de la Plata estuary for the period 19732017 were extracted from the National Direction of Aquatic Resources (DINARA is its acronym in Spanish) reports (compiled in Gianelli \& Defeo 2017) (Fig. 2a). The analysis was conducted at the species level or at a higher taxonomic level in which we were confident of the predominance of a single species (e.g. Mugil spp. and Squatina spp.). This resulted in 21 species or genera representing $95 \%$ of total historical landings. The remaining landings reported in official records were aggregated into higher taxonomic resolution levels and were not considered in this paper. An additional MTC variant (Table 1) was included and analysis was performed by excluding species that comprised $>20 \%$ of landings, following Maharaj et al. (2018). This approach allows MTC to be more representative of species assemblages, avoiding trends that are disproportionately affected by a few dominant species.

The temperature preference for each species was obtained from 2 different sources: (1) Cheung et al. (2013), which inferred temperature preferences from the overlap of species distribution range maps with SST data (average of 1970-2000; see Jones et al. 2012 and supplementary online material of Cheung



Fig. 2. Long-term (1977-2016) variations in (a) Uruguayan industrial fleet landings (total and specific for Argentine hake [A. hake] and whitemouth croaker [W. croaker]) and (b) fishing effort, expressed as the number of vessels operating each year (orange line) and Simpson's index based on the composition of the fishing fleet (light blue line). Landings and fishing effort time series were not linearly correlated $(\mathrm{r}=0.22, \mathrm{p}=0.17)$ et al. 2013 for methods); and (2) FishBase and Sea Life temperature preference data (Froese \& Pauly 2011), based on the Aquamaps (www.aquamaps.org) approach, which uses descriptors of species relationships with environmental variables and expert judgment to predict spatial distributions from publicly available global occurrence databases. In order to assess if the data provided by Cheung et al. (2013) and FishBase were within the physiological temperature preference ranges derived from in situ samples in the region, we reviewed published papers and local grey literature. MTC was computed as the average of the temperature preference of exploited fishes and invertebrate species weighted by their annual catch (Cheung et al. 2013):

$$
\operatorname{MTC}_{y r}=\frac{\sum_{i}^{n} T_{i} C_{i, y r}}{\sum_{i}^{n} C_{i, y r}}
$$

where $C_{i, y r}$ is the catch of species $i$ in year $y r, T_{i}$ is the median temperature preference of species $i$ and $n$ is the total number of species reported from landings within the AUCFZ. For visualization purposes, the MTC anomaly (relative to the 1973-2017 mean) is shown hereafter. The cumulative sum of annual MTC anomaly (MTCcs) was used to detect sustained shifts in the MTC index, marked by changes in slope of the cumulative sum plot (Fiedler 2002 and references therein).

SST and SSTA for the grid delimited by the coordinates $34.5-39^{\circ} \mathrm{S}$ and $52-58.5^{\circ} \mathrm{W}$ were obtained from the IRI/LDEO Climate Data Library (http://iridl.ldeo. columbia.edu 2018; Kalnay et al. 1996, Reynolds et al. 2002). SST and SSTA were calculated by averaging these variables over $4^{\circ} \times 3^{\circ}$ grid cells of the SAO shelf and the adjacent oceanic region. The cumulative sum of annual mean SSTA (SSTAcs) was used to detect sustained changes in climate, marked by a shift in slope of the cumulative sum plot (Fiedler 2002).

\subsection{Temporal pattern in the MTC and modeling}

Segmented regression analyses were used to assess possible shifts in the MTC through time and to detect the breakpoints (year) when MTC changes occur. This procedure was applied to the MTC index considering all species and also excluding the dominant ones (Argentine hake and whitemouth croaker). Multiple linear regression models were also used to explore the relationship between the MTC index, the composition of the Uruguayan fishing fleet for each year and environmental effects (without and with time lag up to $3 \mathrm{yr}$ ). Environmental variables included 
Table 1. Mean temperature of the catch (MTC) variants used in the study. Differences rely on different landing databases used for MTC calculation, the time frame, the taxonomic resolution and the countries involved. CTMFM: Joint Technical Commission of the Uruguayan-Argentinean Maritime Front; AUCFZ: Argentinean-Uruguayan Common Fishing Zone

\begin{tabular}{|lccc|}
\hline MTC variants & $\begin{array}{c}\text { Landings database } \\
\text { used }\end{array}$ & $\begin{array}{c}\text { Time } \\
\text { frame }\end{array}$ & $\begin{array}{c}\text { No. species } \\
\text { considered }\end{array}$ \\
\hline MTC & $\begin{array}{c}\text { Gianelli \& Defeo } \\
(2017)\end{array}$ & $1973-2017$ & 21 \\
MTC excluding main species & $\begin{array}{c}\text { Gianelli \& Defeo } \\
(2017)\end{array}$ & $1973-2017$ & 19 \\
MTC $_{\text {AUCFZ }}$ (Uruguay and Argentina) & CTMFM & $1996-2017$ & 28 \\
\hline
\end{tabular}

not further discuss ENSO effects hereafter, but focus on its most obvious manifestations: the Río de la Plata discharge and SSTA (both directly and indirectly affected by ENSO conditions).

For the period 1996-2017, the CTMFM published landings data with detailed taxonomic resolution (28 species for Uruguay and 25 species for Argentina; Table 1). Thus, we reestimated MTC for the period 19962017 based on CTMFM landings and compared this with the previously described MTC time series (21 species for Uruguay for the period 1973-2017) through correlation analysis and paired sample $t$-tests. Because the CTMFM also compiled Argentinean landings, we estimated MTC for the entire AUCFZ (Uruguayan plus Argentinean landings for the period 1996-2017; Table 1) and compared this with MTC estimated only for Uruguay.

\section{RESULTS}

Segmented regression models showed a marked shift in MTC through time, being characterized by a decreasing trend from 1973 to 1985 and a steady increase over time until 2017 (Fig. 3a). By removing the effect of the 2 dominant species (Merluccius hubbsi and Micropogonias furnieri), the previously observed directional change was reinforced, but the breakpoint occurred later in the record, in 1999 (Fig. 3b).

The regional SSTA increased steadily from the mid1990s with a clear dominance of positive values after 1999 (relative to 1973-2017 climatology: Fig. 4a), a trend particularly noticeable in the temporal analysis of SSTAcs (Fig. 4b). The MTC anomaly showed a pattern similar to that of SSTA (Fig. 4a), particularly after the year 2000. The cumulative sum plot of MTC anomaly and SSTA (Fig. 4b) showed a consistent and positive correlation $(\mathrm{r}=0.88, \mathrm{p}<0.01)$ and a concurrent shift in the cumulative sum slope of both variables. Related changes in both regimes suggest a close association between SST and MTC. This pattern also suggests that between the mid-1990s and 2000, an oceanographic change occurred in the region, which modulated the MTC index including all species (Fig. 4a) and also excluding dominant ones (Fig. 3b).

Multiple linear models showed a close association between MTC, SSTA and fleet diversity, with and without time lags (Table 2). The Río de la Plata discharge anomaly was only statistically significant (see Section 1 in the Supplement). Therefore, we do 


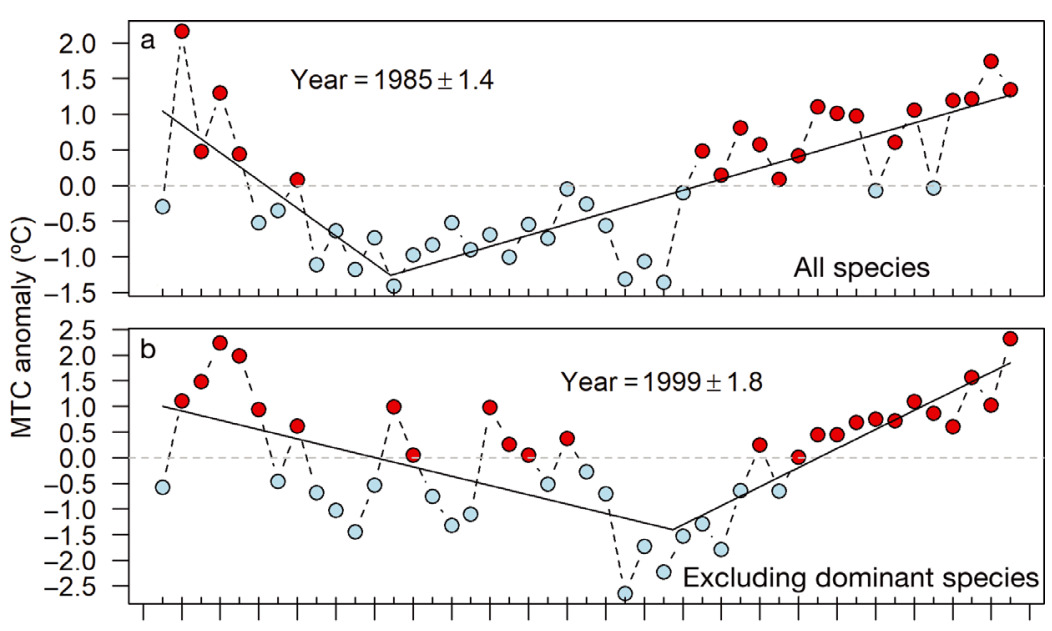

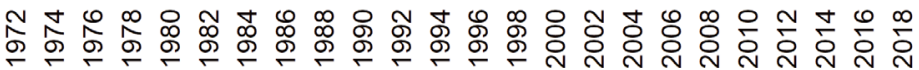

Fig. 3. Mean temperature of the catch $\left(\mathrm{MTC}_{i}{ }^{\circ} \mathrm{C}\right)$ anomaly for Uruguayan landings (1973-2017) in the AUFCZ for (A) all species landed $(\mathrm{n}=21 ; 95 \%$ of total landings); and (B) excluding Merluccius hubbsi and Micropogonias furnieri, which represent nearly $70 \%$ of historical landings. The linear fits of segmented regressions are shown to highlight the increase in MTC since (A) 1985 $\left(R^{2}=0.62\right)$ and (B) $1999\left(R^{2}=0.50\right)$. Red and light-blue circles represent positive and negatives anomalies in MTC, respectively

when considering a 1-yr time lag (Table 2). Based on the different coefficients of determination obtained for models with and without time lags (Table 2), and for the sake of simplicity, we retained the model without a time lag. This model showed that SST and the Simpson index were significant predictors of
MTC (Table 3, Fig. 5). The Río de la Plata discharge anomaly was marginally non-significant $(p=0.057)$ and was thus disregarded from the final model. MTC was positively related with SSTA and negatively related with the Simpson index (regression slopes: 0.43 and -0.44 , respectively). The latter implies that because a particular type of fleet dominated in a given year targeting one or a small group of species (low portfolio diversification), MTC decreased. In contrast, MTC increased when the fleet was more heterogeneous (high portfolio diversification) and provided a more balanced catch composition. The almost equal normalized coefficients (with opposite signs) of SSTA and the Simpson index denoted that both variables are equally important as MTC predictors (Table 3). The final model explained a significant amount of the variance $\left(R^{2}=0.63\right)$ and model residuals did not show temporal autocorrelation (Fig. S2).

MTC estimated using CTMFM landings data for Uruguay (28 species) and the MTC based on Gianelli \& Defeo $(2017 ; 21$ species) exhibited a significant and positive linear correlation $(\mathrm{r}=0.98, \mathrm{p}<0.01)$ for the period 1996-2016. Although the directional pattern remained the same, the more detailed taxonomic res-
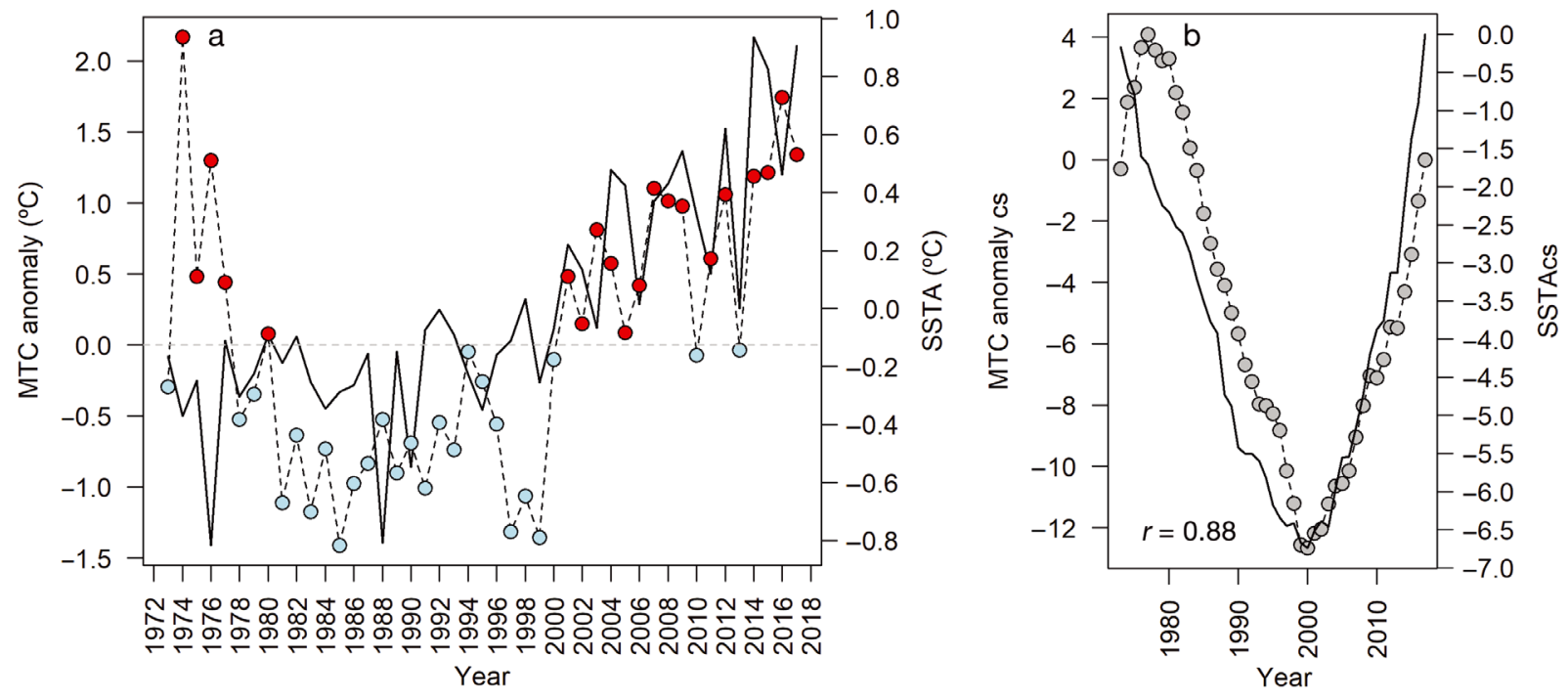

Fig. 4. Long-term variations (1973-2017) in (a) mean temperature of the catch (MTC; ${ }^{\circ} \mathrm{C}$, dashed line) anomaly and sea surface temperature anomaly (SSTA $;{ }^{\circ} \mathrm{C}$, solid line), and (b) cumulative sum of mean temperature of the catch anomaly (MTC anomaly Cs; grey dots and dashed line) and sea surface temperature anomaly (SSTAcs; solid line). In (a), red and light-blue dots represent positive and negatives anomalies in MTC, respectively 
Table 2. Results of linear models between mean temperature of the catch (MTC) and environmental predictors, without and with time lag (up to 3 yr). For all models, the Simpson index ( $z$-score) for fishing fleet diversity was considered without time lag. RdlP: Río de la Plata. ${ }^{*} \mathrm{p}<0.05 ;{ }^{* *} \mathrm{p}<0.01 ;{ }^{* * *} \mathrm{p}<0.001$

\begin{tabular}{|c|c|c|c|c|c|c|c|c|}
\hline \multirow[t]{2}{*}{ Variable } & \multicolumn{2}{|c|}{ — No time lag — } & \multicolumn{2}{|c|}{ - 1-yr time lag - } & \multicolumn{2}{|c|}{-2 -yr time lag - } & \multicolumn{2}{|c|}{-3-yr time lag - } \\
\hline & Estimate & SE & Estimate & SE & Estimate & $\mathrm{SE}$ & Estimate & SE \\
\hline$z$-score SSTA & $0.40^{* *}$ & 0.14 & 0.25 & 0.15 & $0.43^{* *}$ & 0.14 & $0.47^{* *}$ & 0.15 \\
\hline$z$-score Simpson index & $-0.46^{* *}$ & 0.11 & $-0.55^{* * *}$ & 0.14 & $-0.46^{* *}$ & 0.13 & $-0.52^{* * *}$ & 0.13 \\
\hline$z$-score RdlP discharge & -0.19 & 0.09 & $-0.23^{*}$ & 0.109 & -0.16 & 0.11 & -0.08 & 0.11 \\
\hline Intercept & $\begin{array}{c}0.00 \\
\mathrm{R}^{2}: 0.66\end{array}$ & 0.09 & $\begin{array}{c}-0.01 \\
\mathrm{R}^{2}: 0.61\end{array}$ & 0.101 & $\begin{array}{c}0.02 \\
\mathrm{R}^{2}: 0.65\end{array}$ & 0.10 & $\begin{array}{c}0.06 \\
\mathrm{R}^{2}: 0.64\end{array}$ & 0.11 \\
\hline
\end{tabular}

olution for Uruguayan landings registered by the CTMFM influenced the MTC index slightly. The $t$-test for paired samples showed that MTC based on CTMFM was slightly but significantly lower for the analyzed period $(t=-9.26, \mathrm{p}<0.001)$. Additionally, the MTC based on Uruguayan and Argentinean landings (total landings for the AUCFZ) showed a significant linear increase through time $\left(\mathrm{R}^{2}=0.77, \mathrm{p}<0.001\right.$; Fig. 6a), consistent with the MTC pattern observed for Uruguay only for the 1973-2017 period (Fig. 6b).

\section{DISCUSSION}

This study provides the first quantitative evidence that ocean warming has been increasingly affecting Uruguayan industrial fisheries during the past 2 decades. Long-term effects of climate change have led to a shift from cool-water to warm-water species in the relative representation of Uruguayan landings. Furthermore, a significant and consistent association
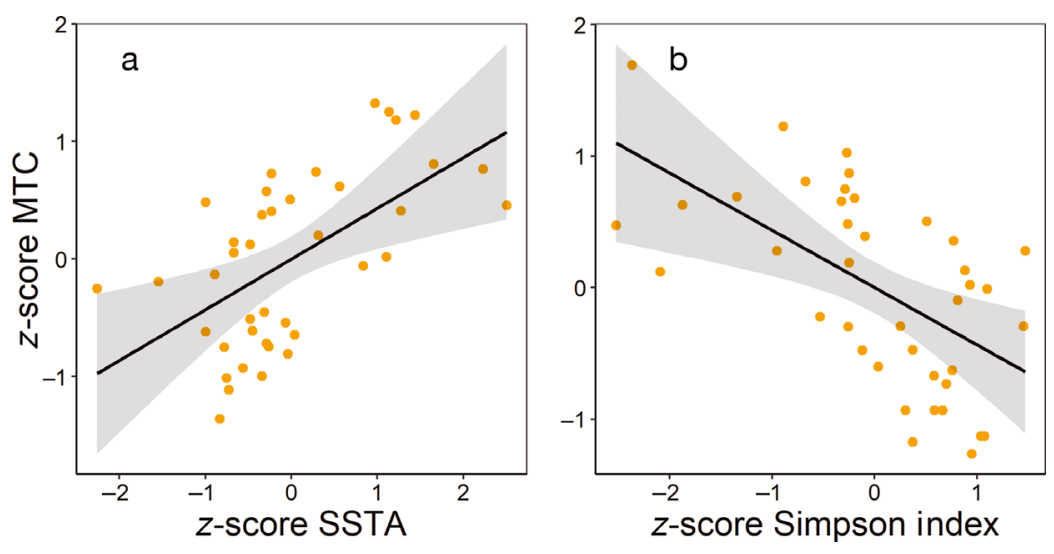

Fig. 5. Mean partial effects of (a) sea surface temperature anomaly ( $z$-score SSTA) and (b) Simpson index applied to the fishing fleet each year ( $z$-score Simpson index) on the mean temperature of the catch (z-score MTC). Gray shading indicates the $95 \%$ confidence interval. All variables were standardized to allow comparisons of slopes between predictors between SST and MTC increase was observed, even when accounting for other drivers such as the composition of the fleet and the influence of freshwater input with large interannual variability. MTC, which symbolizes a sort of thermometer of annual landings, represents a first attempt to address climate change effects on fisheries in the SAO.

Our results suggest that the AUCFZ is a region that is very vulnerable to increased temperature under a warming scenario, and provide evidence that the SAO system and its biota are responding consistently with expectations under ocean warming (Bertrand et al. 2018). The shift from a cold to a warm phase during the 1990s (Ortega et al. 2016), as well as the increase in speed and frequency of onshore (southeast) winds (Escobar et al. 2004, Bischoff 2005), could enhance the advection of warm waters from the Brazil Current to the southern Brazil and Uruguayan shelf. Indeed, Ortega et al. (2016) showed a poleward shift of the warm water front $\left(20^{\circ} \mathrm{C}\right.$; a proxy for the front of tropical waters) of the order of $9 \mathrm{~km} \mathrm{yr}^{-1}$, which was positively correlated with the increase in SSTA, suggesting that ocean warming in this region may be related to changes in broader atmosphere and ocean circulation patterns. A similar southward displacement of the Brazil-Malvinas Confluence has been reported based on satellite and in situ observations (Goni et al. 2011, Lumpkin \& Garzoli 2011) and realistic numerical simulations (Combes \& Matano 2014). The latter indicates that both the Brazil and the Malvinas currents play significant roles in the intensity of shelf circulation (Palma et al. 2008, Matano et al. 2010). Thus, shifts in the Brazil-Malvinas Confluence may lead to significant changes in the circulation inside the AUCFZ. Although the marine species that inhabit this region must be 
Table 3. Linear model relating the mean temperature of the catch (MTC) with the sea surface temperature anomaly (SSTA) and the fishing fleet diversity (Simpson index). ${ }^{* *} \mathrm{p}<0.01$

\begin{tabular}{|lcccc|}
\hline Variable & Estimate & SE & $95 \%$ CI & p-value \\
\hline$Z$-score SSTA & 0.43 & 0.14 & 0.14 to 0.72 & $0.0043^{* *}$ \\
Z-score Simpson Index & -0.44 & 0.14 & -0.72 to -0.15 & $0.0040^{* *}$ \\
Intercept & 0 & 0.10 & -0.19 to 0.19 & \\
& & & & \\
\hline
\end{tabular}

adapted and resilient to these oscillations in oceanographic conditions, the sustained increase in SSTA could lead to unprecedented changes in the composition and structure of ecological assemblages, including extensions/contractions of their geographical range (Horta e Costa et al. 2014). This long-term process may be preceded by an increase in the frequency of records of marine species with tropical affinities (Demicheli et al. 2006, Martínez et al. 2009, Segura et al. 2009, Izzo et al. 2010) and changes in the prevalence of cold-water species towards warm/temperate-water species (Schoeman et al. 2014, Lercari et al. 2018). These results, taken together, support the hypothesis that an increase in MTC in this subtropical region (Cheung et al. 2013) aggravated the crisis of the Uruguayan fishery sector, which is mainly based on the Argentine hake fishery, a species with an affinity for cool water.

The geographical region analyzed here represents an ecotone between the LME of South Brazil and Patagonian Shelf. Transitional characteristics, both in oceanography and biodiversity, place the AUCFZ as a relevant system to assess the effects of climate change on the marine realm. Cheung et al. (2013) showed that the MTC in the South Brazil LME has been fluctuating over the period 1970-2006, whereas MTC in the Patagonian Shelf LME has been decreas-


Fig. 6. (a) Mean temperature of the catch (MTC) anomaly for the ArgentineanUruguayan Common Fishing Zone $\left({ }^{\circ} \mathrm{C}_{i}\right.$ black dots) and Uruguay $\left({ }^{\circ} \mathrm{C}_{i}\right.$ grey dots) based on CTMFM (Joint Technical Commission of the Uruguayan-Argentinean Maritime Front) landings data. (b) Correlation between both time series shown in (a) ing. Two main factors impact the environmental conditions in the AUCFZ. Firstly, variations in the alongshore wind stress modulate seasonal oscillations and the interannual distribution of the Río de la Plata plume (Simionato et al. 2001, Piola et al. 2005, Palma et al. 2008, Matano et al. 2014). In addition, the Subtropical Shelf Front (STSF; Piola et al. 2000) marks an intense subsurface transition between warm-salty subtropical shelf waters and cold-fresh subantarctic shelf waters. Both features exert a significant influence on the distribution of nutrients, suspended matter, zooplankton and ichthyoplankton in the AUCFZ (Ciotti et al. 1995, Muelbert et al. 2008), and seem to delineate the transition between the Patagonian Shelf and South Brazil LMEs. At interannual and longer time scales, the meridional fluctuations of the basin-scale wind fields that modulate the location of the Brazil-Malvinas Confluence may also impact: (1) variations in the distribution of Río de la Plata waters; (2) the location of the STSF; and, therefore, (3) variations in SST that are reported in this study. Such changes would have a significant impact on the AUCFZ and the neighboring shelf ecosystem, suggesting that species inhabiting the boundaries of these LMEs should be resilient to variations, whereas species with trailing range edges of their geographical distribution should be especially vulnerable to climate change. Thus, the limits between these 2 LMEs could be much more dynamic than previously thought, affecting the geographic extension both for subantarctic and subtropical species.

The removal of dominant species from the analysis showed a marked influence of Argentine hake (coolwater affinity) and whitemouth croaker (warm-water affinity) landings in modulating MTC trends. Reduced catch per unit effort (Lorenzo \& Defeo 2015) and landings levels (Gianelli \& Defeo 2017) in Argentine hake for the past 25 yr have been largely attributed to a failure in the management system. However, climate change could be partially responsible for exacerbating the observed trends. Due to the commercial relevance of Argentine hake and the sustained increase in SST in the region, a contraction in the trailing range edge of this species may be expected, deserving urgent research efforts. Further- 
more, recent reports from a nearby region concluded that the reproductive success indexes of Argentine hake were negatively correlated with SST, particularly in autumn (late larval or early juvenile phase; Marrari et al. 2019). In contrast, the wide thermal niche of whitemouth croaker and its affinity for warm waters mean that this species may be less sensitive to an increase in regional SST. Other factors such as the Río de la Plata discharge and coastal pollution are more relevant for the biology of this species. Acha et al. (2012) have shown that high freshwater runoff events promote low retention of eggs and larvae, which would affect the reproductive success of this commercially important species. In addition, interannual variations of Río de la Plata discharge alter the position and distribution of frontal zones and of those species that use them for spawning, such as the whitemouth croaker (Jaureguizar et al. 2016). In this sense, it can be hypothesized that under high freshwater runoff conditions, a greater spatial dispersion of whitemouth croaker will be observed and, therefore, result in a lower catchability for the fishing fleet. The fact that the Río de la Plata discharge variations appear to be confined to the region close to the river mouth (Piola et al. 2005, Matano et al. 2014) could explain the marginal relationship between discharge and MTC (a community index). However, this predictor could be especially meaningful for brackish water species, such as the whitemouth croaker (Jaureguizar et al. 2016).

Managers and decision makers have often left aside the effects of climate change on fisheries to focus on traditional fisheries management and the pressing threat of overfishing. However, the present study suggests that there is a need to consider the effects of environmental changes to properly manage stocks located in a dynamic warming hotspot, particularly those shared by neighboring countries. The consistent results in terms of the increase in MTC using different landing databases for the entire AUCFZ during 1996-2016 (considering Uruguayan and Argentinean landings) call for a regional cooperation strategy. As the responsible governance body, the CTMFM will have to deal with stock distributions becoming less predictable and traditional fisheries declining or new fisheries emerging. Existing fisheries management and governance schemes are largely based on the premise that fish stock distribution ranges remain relatively static through time (Gutiérrez \& Defeo 2013). However, as already observed in several regions and predicted at a global scale (Pinsky et al. 2018), many fish stocks will likely shift across national and other political boundaries in the coming decades. Thus, cooperative management will play a critical role for facing conflicts over newly or no longer shared resources due to the effects of climate change in this region (Villasante \& Österblom 2015).

Our study leaves open several issues related to: (1) strategies to be explored by the Uruguayan government and/or its industrial fishery sector to cope with changing oceans; (2) the need to carry out regional studies by incorporating detailed long-term Argentine landings data and including fishery-independent surveys to provide robust lines of evidence for the AUCFZ; $_{i}(3)$ the need to manage fish stocks based on model projections, not merely on historical and static assumptions about the distribution and abundance of the species; and, finally, (4) assess the potential for regional multinational collaboration on fisheries and ocean sustainability issues. The latter issue needs to be implemented on a scale large enough to capture the impacts of climate change on regional fisheries of the SAO.

Acknowledgements. We are grateful for the support provided by the Inter-American Institute for Global Change Research (grant CRN 3070), which is supported by the US National Science Foundation (Grant GEO - 474 1128040), and by Comisión Sectorial de Investigación Científica (CSIC Grupos ID 32). We thank the 2 anonymous reviewers and A. Hobday for their thoughtful revision and constructive comments and suggestions. This paper is part of the $\mathrm{PhD}$ thesis of Y. Marín.

\section{LITERATURE CITED}

Acha EM, Mianzan HW, Guerrero RA, Favero M, Bava J (2004) Marine fronts at the continental shelves of austral South America: physical and ecological processes. J Mar Syst 44:83-105

Acha EM, Simionato CG, Carozza C, Mianzan H (2012) Climate-induced year-class fluctuations of whitemouth croaker Micropogonias furnieri (Pisces, Sciaenidae) in the Río de la Plata estuary, Argentina-Uruguay. Fish Oceanogr 21:58-77

Alheit J, Licandro P, Coombs S, Garcia A and others (2014) Atlantic Multidecadal Oscillation (AMO) modulates dynamics of small pelagic fishes and ecosystem regime shifts in the eastern North and Central Atlantic. J Mar Syst 133:88-102

Allison EH, Perry AL, Badjeck MC, Adger WN and others (2009) Vulnerability of national economies to the impacts of climate change on fisheries. Fish Fish 10:173-196

Barange M, Cheung WWL, Merino G, Perry RI (2010) Modelling the potential impacts of climate change and human activities on the sustainability of marine resources. Curr Opin Environ Sustain 2:326-333

Barreiro M (2010) Influence of ENSO and the South Atlantic Ocean on climate predictability over Southeastern South America. Clim Dyn 35:1493-1508

Bertrand A, Vögler R, Defeo O (2018) Climate change impacts, vulnerabilities and adaptations: Southwest Atlantic and 
Southeast Pacific marine fisheries. In: Barange M, Bahri $\mathrm{T}$, Beveridge MC, Cochrane KL, Funge-Smith S, Poulain $\mathrm{F}$ (eds) Impacts of climate change on fisheries and aquaculture. FAO, Rome, p 325-346

Bischoff S (2005) Sudestadas. In: Barros V, Menéndez A, Nagy G (eds) El cambio climático en el Río de la Plata. UBA, Buenos Aires, p 53-67

Blanchard JL, Watson RA, Fulton EA, Cottrell RS and others (2017) Linked sustainability challenges and trade-offs among fisheries, aquaculture and agriculture. Nat Ecol Evol 1:1240-1249

Borús J, Uriburu Quirno M, Calvo D (2017) Evaluación de caudales mensuales descargados por los grandes ríos del sistema del plata al estuario del Río de la Plata. Alerta Hidrológico - Instituto Nacional del Agua y el Ambiente, Ezeiza

* Cheung WWL, Lam VWY, Sarmiento JL, Kearney K, Watson R, Pauly D (2009) Projecting global marine biodiversity impacts under climate change scenarios. Fish Fish 10: 235-251

Cheung WWL, Watson R, Pauly D (2013) Signature of ocean warming in global fisheries catch. Nature 497:365-368

Cheung WWL, Bruggeman J, Butenschön M (2018) Projected changes in global and national potential marine fisheries catch under climate change scenarios in the twenty-first century. In: Barange $M$, Bahri $T$, Beveridge MC, Cochrane KL, Funge-Smith S, Poulain F (eds) Impacts of climate change on fisheries and aquaculture. FAO, Rome, p 63-85

Ciotti ÁM, Odebrecht C, Fillmann G, Moller OO Jr (1995) Fresh water out flow and subtropical convergence influence on phytoplankton biomass on the southern Brazilian continental shelf. Cont Shelf Res 15:1737-1756

Cline TJ, Schindler DE, Hilborn R (2017) Fisheries portfolio diversification and turnover buffer Alaskan fishing communities from abrupt resource and market changes. Nat Commun 8:14042

Colberg F, Reason CJC, Rodgers K (2004) South Atlantic response to El Niño-Southern Oscillation induced climate variability in an ocean general circulation model. J Geophys Res Oceans 109:C12015

* Combes V, Matano RP (2014) Trends in the Brazil/Malvinas Confluence region. Geophys Res Lett 41:8971-8977

Costello C (2018) Does climate change bolster the case for fishery reform in Asia? Asian Dev Rev 35:31-57

* Demicheli M, Martínez A, Ortega L, Scarabino F, Maytía S, Demicheli A (2006) Mass stranding of Argonauta nodosa Lightfoot, 1786 (Cephalopoda, Argonautidae) along the Uruguayan coast (southwestern Atlantic). Rev Biol Mar Oceanogr 41:1-7

Dulvy NK, Rogers SI, Jennings S, Stelzenmüller V, Dye SR, Skjoldal HR (2008) Climate change and deepening of the North Sea fish assemblage: a biotic indicator of warming seas. J Appl Ecol 45:1029-1039

Escobar G, Vargas W, Bischoff S (2004) Wind tides in the Río de la Plata estuary: meteorological conditions. Int J Climatol 24:1159-1169

Fiedler PC (2002) Environmental change in the eastern tropical Pacific Ocean: review of ENSO and decadal variability. Mar Ecol Prog Ser 244:265-283

* Free CM, Thorson JT, Pinsky ML, Oken KL, Wiedenmann J, Jensen OP (2019) Impacts of historical warming on marine fisheries production. Science 363:979-983

Froese R, Pauly D (2011) FishBase. www.fishbase.org (accessed 10 June 2018)
Gaines SD, Costello C, Owashi B, Mangin T and others (2018) Improved fisheries management could offset many negative effects of climate change. Sci Adv 4:eaao1378

* Gianelli I, Defeo O (2017) Uruguayan fisheries under an increasingly globalized scenario: long-term landings and bioeconomic trends. Fish Res 190:53-60

* Goni GJ, Bringas F, DiNezio PN (2011) Observed low frequency variability of the Brazil Current front. J Geophys Res Oceans 116:C10037

*Gordon AL (1989) Brazil-Malvinas Confluence-1984. Deep Sea Res A Oceanogr Res Pap 36:359-384

* Guerrero RA, Acha EM, Framin MB, Lasta CA (1997) Physical oceanography of the Río de la Plata Estuary, Argentina. Cont Shelf Res 17:727-742

Gutiérrez NL, Defeo O (2013) Evaluación de recursos pesqueros de Uruguay mediante modelos dinámicos. MGAPDINARA, FAO, Rome

Hobday AJ, Pecl GT (2014) Identification of global marine hotspots: sentinels for change and vanguards for adaptation action. Rev Fish Biol Fish 24:415-425

*Hobday AJ, Cochrane K, Downey-Breedt N, Howard J and others (2016) Planning adaptation to climate change in fast-warming marine regions with seafood-dependent coastal communities. Rev Fish Biol Fish 26:249-264

* Hoegh-Guldberg O, Bruno JF (2010) The impact of climate change on the world's marine ecosystems. Science 328: 1523-1528

* Horta e Costa B, Assis J, Franco G, Erzini K, Henriques M, Gonçalves EJ, Caselle JE (2014) Tropicalization of fish assemblages in temperate biogeographic transition zones. Mar Ecol Prog Ser 504:241-252

Izzo P, Milessi AC, Ortega L, Segura AM (2010) First record of Aluterus scriptus (Monacanthidae) in Mar del Plata, Argentina. Mar Biodivers Rec 3:e40

* Jaureguizar AJ, Solari A, Cortés F, Milessi AC and others (2016) Fish diversity in the Río de la Plata and adjacent waters: an overview of environmental influences on its spatial and temporal structure. J Fish Biol 89:569-600

* Jones MC, Dye SR, Pinnegar JK, Warren R, Cheung WWL (2012) Modelling commercial fish distributions: prediction and assessment using different approaches. Ecol Modell 225:133-145

Kalnay E, Kanamitsu M, Kistler R, Collins W and others (1996) The NCEP/NCAR 40-year reanalysis project. Bull Am Meteorol Soc 77:437-471

Keskin C, Pauly D (2014) Changes in the 'Mean Temperature of the Catch': application of a new concept to the North-eastern Aegean Sea. Acta Adriat 55:213-218

* Lercari D, Defeo O, Ortega L, Orlando L, Gianelli I, Celentano E (2018) Long-term structural and functional changes driven by climate variability and fishery regimes in a sandy beach ecosystem. Ecol Modell 368:41-51

* Liang C, Xian W, Pauly D (2018) Impacts of ocean warming on China's fisheries catches: an application of 'mean temperature of the catch' concept. Front Mar Sci 5:26

Lorenzo MI, Defeo O (2015) The biology and fishery of hake (Merluccius hubbsi) in the Argentinean-Uruguayan Common Fishing Zone of the Southwest Atlantic Ocean. In: Arancibia H (ed) Hakes: biology and exploitation. John Wiley \& Sons, Chichester, p 185-210

* Lumpkin R, Garzoli S (2011) Interannual to decadal changes in the western South Atlantic's surface circulation. J Geophys Res Oceans 116:C01014

* Madin EMP, Ban NC, Doubleday ZA, Holmes TH, Pecl GT, Smith F (2012) Socio-economic and management impli- 
cations of range-shifting species in marine systems. Glob Environ Change 22:137-146

Maharaj RR, Lam VWY, Pauly D, Cheung WWL (2018) Regional variability in the sensitivity of Caribbean reef fish assemblages to ocean warming. Mar Ecol Prog Ser 590:201-209

Marín YH (2016) La pesca industrial uruguaya desde la perspectiva de los sistemas social-ecológicos. MSc thesis, University of the Republic, Montevideo

Marrari M, Macchi GJ, Santos B, Leonarduzzi E (2019) Influence of environmental conditions on the reproductive success and recruitment of the Argentine hake Merluccius hubbsi (southwestern Atlantic Ocean). Fish Oceanogr 28:66-81

Martínez G, Scarabino F, Delgado E (2009) New records of the brachyuran crabs Hepatus pudibundus (Aethridae) and Persephona mediterranea (Leucosiidae) in their southernmost Western Atlantic distribution. J Aquat Sci 4:279-282

Matano RP, Palma ED, Piola AR (2010) The influence of the Brazil and Malvinas Currents on the Southwestern Atlantic Shelf circulation. Ocean Sci 6:983-995

Matano RP, Combes V, Piola AR, Guerrero R and others (2014) The salinity signature of the cross-shelf exchanges in the southwestern Atlantic Ocean: numerical simulations. J Geophys Res Oceans 119:7949-7968

McLachlan A, Defeo O (2018) The ecology of sandy shores, 3rd edn. Academic Press, London

Muelbert JH, Acha M, Mianzan H, Guerrero R and others (2008) Biological, physical and chemical properties at the Subtropical Shelf Front Zone in the SW Atlantic Continental Shelf. Cont Shelf Res 28:1662-1673

* Ortega L, Martínez A (2007) Multiannual and seasonal variability of water masses and fronts over the Uruguayan shelf. J Coast Res 23:618-629

* Ortega L, Castilla JC, Espino M, Yamashiro C, Defeo O (2012) Effects of fishing, market price, and climate on two South American clam species. Mar Ecol Prog Ser 469:71-85

* Ortega L, Celentano E, Delgado E, Defeo O (2016) Climate change influences on abundance, individual size and body abnormalities in a sandy beach clam. Mar Ecol Prog Ser 545:203-213

Österblom H, Crona BI, Folke C, Nyström M, Troell M (2017) Marine ecosystem science on an intertwined planet. Ecosystems 20:54-61

* Palma ED, Matano RP, Piola AR (2008) A numerical study of the southwestern Atlantic shelf circulation: stratified ocean response to local and offshore forcing. J Geophys Res Oceans 113:C11010

Pauly D, Cheung WWL (2018) Sound physiological knowledge and principles in modeling shrinking of fishes under climate change. Glob Change Biol 24:e15-e26

Pecl GT, Araújo MB, Bell JD, Blanchard J and others (2017). Biodiversity redistribution under climate change: impacts on ecosystems and human well-being. Science 355: eaai9214

Perry AL, Low PJ, Ellis JR, Reynolds JD (2005) Climate change and distribution shifts in marine fishes. Science 308:1912-1915

Editorial responsibility: Alistair Hobday,

Hobart, Tasmania, Australia
Pinsky ML, Worm B, Fogarty MJ, Sarmiento JL, Levin SA (2013) Marine taxa track local climate velocities. Science 341:1239-1242

* Pinsky ML, Reygondeau G, Caddell R, Palacios-Abrantes J, Spijkers J, Cheung WWL (2018) Preparing ocean governance for species on the move. Science 360:1189-1191

* Piola AR, Campos EJ, Möller OO Jr, Charo M, Martinez C (2000) Subtropical shelf front of eastern South America. J Geophys Res 105:6565-6578

Piola AR, Matano RP, Palma ED, Möller OO Jr, Campos EJD (2005) The influence of the Plata River discharge on the western South Atlantic shelf. Geophys Res Lett 32: L01603

Piola AR, Palma ED, Bianchi AA, Castro BM and others (2018) Physical oceanography of the SW Atlantic Shelf: a review. In: Hoffmeyer M, Sabatini ME, Brandini F, Calliari D, Santinelli NH (eds) Plankton ecology of the Southwestern Atlantic. Springer, Cham, p 37-56

R Core Team (2018) R: a language and environment for statistical computing. R Foundation for Statistical Computing, Vienna, www.r-project.org

* Reynolds RW, Rayner NA, Smith TM, Stokes DC, Wang W (2002) An improved in situ and satellite SST analysis for climate. J Clim 15:1609-1625

* Reynolds RW, Smith TM, Liu C, Chelton DB, Casey KS, Schlax MG (2007) Daily high-resolution blended analyses for sea surface temperature. J Clim 20:5473-5496

Schoeman DS, Schlacher TA, Defeo O (2014) Climate change impacts on sandy-beach biota: crossing a line in the sand. Glob Change Biol 20:2383-2392

* Segura AM, Carranza A, Rubio LE, Ortega L, García M (2009) Stellifer rastrifer (Pisces: Sciaenidae): first Uruguayan records and a $1200 \mathrm{~km}$ range extension. Mar Biodivers Rec 2:e67

* Simionato CG, Nuñez MN, Engel M (2001) The salinity front of the Río de la Plata-a numerical case study for winter and summer conditions. Geophys Res Lett 28: 2641-2644

*Tsikliras AC, Stergiou KI (2014) Mean temperature of the catch increases quickly in the Mediterranean Sea. Mar Ecol Prog Ser 515:281-284

* Tsikliras AC, Peristeraki P, Tserpes G, Stergiou KI (2015) Mean temperature of the catch (MTC) in the Greek Seas based on landings and survey data. Front Mar Sci 2:23

* Tsikliras AC, Licandro P, Pardalou A, McQuinn IH, Gröger JP, Alheit J (2019) Synchronization of Mediterranean pelagic fish populations with the North Atlantic climate variability. Deep Sea Res II 159:143-151

*Villasante S, Österblom H (2015) The role of cooperation for improved stewardship of marine social-ecological systems in Latin America. Ecol Soc 20:8

Villasante S, Macho G, Isusu de Rivero J, Divovich E, Zylich K, Zeller D, Pauly D (2016) Argentina. In: Pauly D, Zeller $\mathrm{D}$ (eds) Global atlas of marine fisheries: a critical appraisal of catches and ecosystem impacts. Island Press, Washington, DC, p 190

Z Zhou S, Smith AD, Punt AE, Richardson AJ and others (2010) Ecosystem-based fisheries management requires a change to the selective fishing philosophy. Proc Natl Acad Sci USA 107:9485-9489

Submitted: September 24, 2018; Accepted: June 14, 2019

Proofs received from author(s): August 15, 2019 